\title{
The Effect of The Solar Heat Flux to The Optimized Solar Chimney Power Plant: An Experimental Study
}

\author{
H.M.I. Paska ${ }^{1}$, A. Widyaparaga ${ }^{1}$, Fauzun 1 , A. Ridwan ${ }^{2}$, R. Abdurrahman ${ }^{2}$ \\ ${ }^{1}$ Department of Mechanical and Industrial Engineering, Faculty of Engineering, University of Gadjah Mada \\ Grafika Street No. 2, Yogyakarta 55281 Phone. +62-274-521673 \\ ${ }^{2}$ Department of Mechanical Engineering, Faculty of Engineering, University of Muhammadiyah Riau \\ Tuanku Tambusai Street, Pekanbaru, Riau 28294 Phone. +62-761-839577 \\ E-mail:*1herymadapaska@gmail.com
}

\begin{abstract}
The Solar Chimney Power Plant (SCPP) is an energy conversion system that would absorb solar thermal energy and convert heat air into electrical energy using a collector. The main disadvantage of the SCPP is that low efficiency because less solar heat flux can be converted to the electrical power affected by the design of the SCPP. This study was designed the SCPP by theoretical calculation for producing electrical power and experimented by designing the SCPP use a chimney with divergent shape, a collector with convergent shape, a turbine generator with 3 blades, and coating some materials at the collector's ground to increasing the electrical power. The purpose of this work was to study about the impact of the solar heat flux $(I)$ to the temperature of air, to the velocity of air, to the power electricity and compare between power generated from theoretical calculations design and the experiments result. The result showed that the SCPP with the optimized design affect the performance of the SCPP's output power. The power generated in this experiment is $0.1 \mathrm{Watt}$. That value is greater than output power from theoretical calculations about $42.8 \%$ for the same input solar heat flux (I) $1118 \mathrm{~W} / \mathrm{m}^{2}$ both for theoritical and experimental.
\end{abstract}

Keywords: Solar Chimney Power Plant, Blades, Collector's Ground, Turbine Generator.

\begin{abstract}
Abstrak
Solar Chimney Power Plant (SCPP) adalah sistem konservasi energi yang menyerap energi panas matahari dan menkonversi panas menjadi energi listrik menggunakan kolektor. Kelemahan utama dari SCPP adalah memiliki efisiensi yang rendah karena sedikitnya intensitas matahari yang dapat dikonversi menjadi daya listrik. Hal tersebut salah satunya disebabkan oleh desain SCPP yang belum optimal. Penelitian ini mendesain SCPP menggunakan perhitungan secara teori untuk menghasilkan energi listrik dan menguji secara eksperimen dengan menggunakan desain SCPP dengan cerobong berbentuk divergen, kolektor berbentuk konvergen, generator turbin dengan 3 sudu, dan memberi lapisan pada dasar kolektor dengan bahan yang dapat meningkatkan keluaran daya listrik. Tujuan penelitian ini adalah untuk mempelajari pengaruh intensitas matahari (I) terhadap suhu udara, kecepatan udara, daya listrik dan membandingkan hasil perhitungan secara teori dengan eksperimen. Hasil yang diperoleh dari penelitian ini
\end{abstract}


menunjukan bahwa SCPP dengan optimasi desain berpengaruh pada performa keluaran SCPP. Daya yang dihasilkan dari eksperimen sebesar $0.1 \mathrm{Watt}$. Nilai tersebut lebih besar $42.8 \%$ daripada daya keluaran yang dihasilkan pada perhitungan secara teoritis untuk nilai input intensitas matahari (I) yang sama yaitu $1118 \mathrm{~W} / \mathrm{m}^{2}$.

Keywords: Solar Chimney Power Plant, Sudu, Dasar Kolektor, Generator Turbin.

\section{INTRODUCTION}

The limitation of fossil fuels as the supplier energy was caused by the amount of energy usage in the world. The new concept was needed to control the use of fossil fuel by used renewable energy. Renewable energy sources are recognized as a substitute for fossil fuels that are suitable for fulfill current energy needed. One of the system that utilize the solar energy to produce power is the solar chimney power plant (SCPP). The SCPP have three main part, there were solar collector, the chimney, and the turbine as the convertion unit. The SCPP system is interesting to be developed because it has several advantages including the needed of very low cost of maintenance and very low operational sound (Zuo et al., 2019).

Several studies were investigated about SCPP. Dehghani, et al (2012) investigated SCPP in Iran, the system received radiation of $400-750 \mathrm{~W} / \mathrm{m}^{2}$, with $270-315 \mathrm{~K}$, ambient temperature and the diameter of collector of 1000 meters, the tower height of 350 meters. The result of their experiment was generated 1-2 MW electric energy (Dehghani and Mohammadi, 2014).

A. Ridwan, et al (2018) investigated the SCPP with height tower chimney of $193 \mathrm{~cm}$ and the inner diameter of 0,83 meters. The dimension of SCPP and experimental data were tested. The SCPP was made with the dimension of $1.3225 \mathrm{~m}^{2}$ in collector as a cover area and the thickness was $5 \mathrm{~mm}$. The material of collector ground in that study was made from aluminum foil, carpet and styrofoam. The targeted output power in their theoretic calculation was 0.03 Watt while the actual experiment values ranged between $0.0133-0.0317$ Watt. The targeted inlet air velocity from theoretical calculation was $2.15 \mathrm{~m} / \mathrm{s}$ while the actual experiment value varied from $1.4 \mathrm{~m} / \mathrm{s}$ to around $2.2 \mathrm{~m} / \mathrm{s}$. The result obtained from their experiment were showed that in Riau Province, the potential of SCPP system able to be assess.

Auryubi, et al (2018) was investigated SCPP with the chimney dimension 6.5 meters of height, and 0.15 meters of inner diameter. The collector was made of acrylic, and it was a circle shape with a diameter of 6 meters. In Auryubi's experiment, they add thermal enhancing channel to collector of the SCPP. Those additional channel increase air temperature inside collector. The wall temperature of thermal enhancing channels is $100^{\circ} \mathrm{C}$ as the result of solar heat flux $(I) 1000 \mathrm{~W} / \mathrm{m}^{2}$. The value of power generation with enhancing channel is $23.1 \%$ greater than power generation without enhancing channels. Also for air temperature inside the collector, the value is increase about 5.88\% greater than SCPP without enhancing channels.

Several experiments were explained that the SCPP performance can be improved by choosing the right dimension for the chimney like the height and the inclination of the chimney, the area inclination of the collector, the amount of solar heat flux, the number of blade turbines, and others. The purpose of this study was to know about the effect of the solar heat flux (I) to the air temperature (ambient temperature $\left(T_{a m b}\right)$, chimney neck temperature $\left(T_{a i r, o}\right)$, and collector temperature $\left(T_{c}\right)$ ), to the air velocity (ambient wind velocity $\left(u_{w}\right)$ and chimney neck air velocity $\left.\left(v_{o, c o l l}\right)\right)$, to the electrical power and compare the power generated from theoretical calculations design to the experiments result. In this experiment, the SCPP design was optimized 
to improve its performance by designing the divergent chimney (Hu et al., 2016), the convergent collector, using 3 blades of the turbine, and coating the top side of the collector ground with asphalt that used concrete and gravel for the materials (Ghalamchi et al., 2016).

\section{EXPERIMENTAL APPARATUS AND PROCEDURES}

In this experiment, the data variables were collected to design the SCPP and testing the system. The dimensions of design were obtained from mathematical equation that shown at Equation 2 until Equation 10. That dimension then used as the basis for built a SCPP design.

\begin{tabular}{|c|c|}
\hline \multicolumn{2}{|c|}{ Nomenclature } \\
\hline$I$ & Solar heat flux $\left(\mathrm{W} / \mathrm{m}^{2}\right)$ \\
\hline$T_{a m b} T_{a i r, i}$ & ambient temperature $(\mathrm{K})$ \\
\hline$T_{\text {air }, o} T_{c} T_{g}$ & $\begin{array}{l}\text { chimney neck temperature (temperature at the turbine), cover temperature, and } \\
\text { ground temperature, respectively }(\mathrm{K})\end{array}$ \\
\hline$u_{w}$ & ambient air velocity $(\mathrm{m} / \mathrm{s})$ \\
\hline$v_{o \text { coll }}$ & velocity of air in the neck chimney (at the turbine) $(\mathrm{m} / \mathrm{s}$ ) \\
\hline$A_{c h} A_{c} A_{g}$ & $\begin{array}{l}\text { neck chimney's surface area, colector cover's surface area, and colector ground's } \\
\text { surface area, respectively }\left(\mathrm{m}^{2}\right)\end{array}$ \\
\hline$H_{c h}$ & chimney's height $(\mathrm{m})$ \\
\hline$P_{\text {ele }}$ & electrical power (Watt) \\
\hline$P_{T U R, M A X}$ & turbine power (Watt) \\
\hline$P_{\text {KINETIC WIND }}$ & wind kinetic power (Watt) \\
\hline$\Delta P_{\text {out }}$ & $\begin{array}{l}\text { Differentiation in SCPP output power between output power targeted } \\
\text { and output power from experiment (Watt) }\end{array}$ \\
\hline$P_{e x}$ & The output power generated in the experiment (Watt) \\
\hline$P_{t h}$ & The output power generated in the theoritical design calculation (Watt) \\
\hline$\eta_{\text {turbine }}$ & eficiency of turbine $(\%)$ \\
\hline$\eta_{\text {generator }}$ & eficiency of generator $(\%)$ \\
\hline$\theta$ & colector's inclination $\left({ }^{\circ}\right)$ \\
\hline$L_{g-c}$ & average distance between collector cover and collector ground (m) \\
\hline$\rho_{\text {air }}$ & air density $\left(\mathrm{kg} / \mathrm{m}^{3}\right)$ \\
\hline$\dot{m}$ & mass flow rate of air $(\mathrm{kg} / \mathrm{s})$ \\
\hline$h_{\text {con,c-air }}$ & $\begin{array}{l}\text { convective heat transfer coefficient from cover to air inside } \\
\text { collector }\left(\mathrm{W} / \mathrm{m}^{2} \mathrm{~K}\right)\end{array}$ \\
\hline$h_{\text {con,g-air }}$ & $\begin{array}{l}\text { convective heat transfer coefficient from ground to air inside } \\
\text { collector }\left(\mathrm{W} / \mathrm{m}^{2} \mathrm{~K}\right)\end{array}$ \\
\hline$h_{r, g-c}$ & radiation heat transfer coefficient from ground to cover $\left(W / \mathrm{m}^{2} \mathrm{~K}\right)$ \\
\hline$L_{u}$ & coefficient of heat loss from the outer cover's surface to the ambient $\left(\mathrm{W} / \mathrm{m}^{2} \mathrm{~K}\right)$ \\
\hline$L_{d}$ & Thermal Conductivity $\left(\mathrm{W} / \mathrm{m}^{2} \mathrm{~K}\right)$ \\
\hline$D_{\text {coll }}$ & diameter of Collector (m) \\
\hline$\propto_{c} \propto_{g}$ & absorptivity of the collector cover and ground, respectively \\
\hline$\varepsilon_{c} \varepsilon_{g}$ & emmisivity of the collector cover and ground, respectively \\
\hline$\tau_{c}$ & transmissivity of the collector \\
\hline$\mu$ & dynamic viscosity $(\mathrm{kg} / \mathrm{m} \mathrm{s})$ \\
\hline$C_{p}$ & specific Heat $(\mathrm{J} / \mathrm{kg} \mathrm{K})$ \\
\hline$K_{\text {air }}$ & thermal Conductivity $(\mathrm{W} / \mathrm{m} \mathrm{K})$ \\
\hline$v$ & kinematic viscosity $\left(\mathrm{m}^{2} / \mathrm{s}\right)$ \\
\hline
\end{tabular}

In this experiment the SCPP was designed on Production Process Laboratory. Several data would be taken after SCPP was build to compare with variable result in theoretic 
calculation. The construction design of the SCPP was made with high precision to minimize losses and data error. The material used was based on physical property, economic value and availability on the market. The material used for the cover and ground were followed to the assumption the design such as the value of absorptivity, transmisivity and emissivity.

The chimney shape in this experiment was designed using divergent shape to optimize the airflow. Aluminium used as the material of the chimney. From the mathematical calculation and iteration process, the height $\left(H_{c h}\right)$ and the area $\left(A_{c h}\right)$ of the chimney was obtained. The collector shape in this experiment designed with convergent form. This shape was made to increasing air velocity in the collector. The collector has three part, those are collector cover, collector ground, and collector cover stand. The collector cover used an acrylic material as a heat collector from solar heat flux. The space between cover collector and ground collector as the air inlet, designed liked a nozzle. Those was used to increased the air entered the system. The collector's ground was used asphalt layer at the top and then followed by concrete and gravel at below. The asphalt and the concrete was selected as a material because it could be absorb and keep the heat as well and it would be optimum to produce a power. The proposed model in this study is shown in Figure 1 as a schematic diagram.

The previous research by Aurybi et al (2018) showed that the main parts of the SCPP consist of two parts; the chimney and the collector. In this study, the mathematical model was made to established and to enhance the collector and the chimney performance. The continuity, momentum, and energy equation were solved using mathematical model. Aurybi also using performance equations of the system to calculate efficiency and power output from the system. The mathematical model calculation and performance equation in this study were adopted from Aurbi's study.

\subsection{Mathematical Calculation}

From Figure. 1 we can show that the solar heat flux heated the air inside the collector. The increasing of air temperature inside $\left(T_{\text {air }}\right)$ makes airflow through the center of the collector and then the air exits through the chimney due to temperature differences or natural convection. The mathematical model was used to estimate the temperature distribution at the collector cover $\left(T_{c}\right)$, at the ground collector $\left(T_{g}\right)$ and the air inside the collector $\left(T_{\text {air }}\right)$. The generator was a converter of mechanical power (input) into electrical power (output), in the real situation all of input power cannot be converted to the electrical power due to mechanical losses. The efficiency $(\eta)$ was the ratio between output power and input power, and always less than $100 \%$. This study was assumed that solar chimney would be generated power of 0.07 Watts. Aurybi et al (2018) explained that an electrical power was affected by turbine efficiency $(80 \%)$ and generator efficiency $(95 \%)$ of maximum turbine power. Therefore it was important to identify the losses power that causes of efficiency decreased.

$$
P_{\text {ele }}=\eta_{\text {turbine }} \cdot \eta_{\text {generator }} \cdot P_{T U R, M A X}
$$

Equation 1 showed that the electrical power equal to the multiplication of the turbine efficiency $\left(\eta_{\text {turbine }}\right)$, the generator efficiency $\left(\eta_{\text {generator }}\right)$ and maximum turbin power $P_{T U R, M A X}$. Maximum turbine power was the maximum power that obtained from the air that passes trough to the turbine. In this case represented as a constanta $(C)$ with an ideal value of $\frac{2}{3}$. The constanta $(C)$ was represented as the ratio between the pressure drop of turbine and the overall pressure 
potential[8]. This coefficient has a different value between 0 and 1 . The maximum turbine power can be calculated using the equation below:

$$
P_{T U R, M A X}=\frac{2}{3} \cdot P_{\text {KINETIC WIND }}
$$

The air that was entered into the collector of SCPP has potential energy. The potential energy of the air was depend on the air flow rate $(\dot{m})$, gravitation $(\mathrm{g})$, height of chimney $\left.\left(H_{c h}\right)\right)$, and temperature differences (Zhou et al., 2007). In this experiment, the turbine was in the chimney neck. When the air drived the turbine the potential energy was turned into kinetic energy. Therefore the potential energy was equal to the kinetic energy (Zhou et al., 2007). The power generated from kinetic energy of air can obtained from the equation below:

$$
P_{\text {KINETIC WIND }}=\frac{1}{3} \rho_{\text {air }} \cdot A \cdot v_{o, \text { coll }}^{3}
$$

Where $P_{\text {KINETIC WIND }}$ is the power generated by kinetic energy of the air (Watt). $\rho_{\text {air }}$ is density of air $\left(\mathrm{kg} / \mathrm{m}^{3}\right)$. A is a collector surface area $\left(\mathrm{m}^{2}\right) \cdot v_{o, \text { coll }}$ is velocity of air in the chimney neck (Koonsrisuk and Chitsomboon, 2013).

All of variables were known from collecting data with measuring devices as a basis for the initial calculation of the design in the SCPP. These variables include $I, \alpha_{c}, T_{a m b}, \tau_{c}, \alpha_{g}$, , $L_{d}, T_{a i r, i}=T_{a m b}, \sigma, \varepsilon_{g}, \varepsilon_{c}$, and $u_{w}$. All values of variables shown in Table 1.

The parameter of variable were determined by assumed the theoretical calculations of the SCPP design process. In this study variable parameters that assumed were $A_{g}=A_{c}, A_{c h}$, $T_{\text {air }}, T_{g}, T_{c}, \theta=3^{\circ}, L_{g-c}=0.275 \mathrm{~m}$. All values of variable parameters also shown in Table 1.

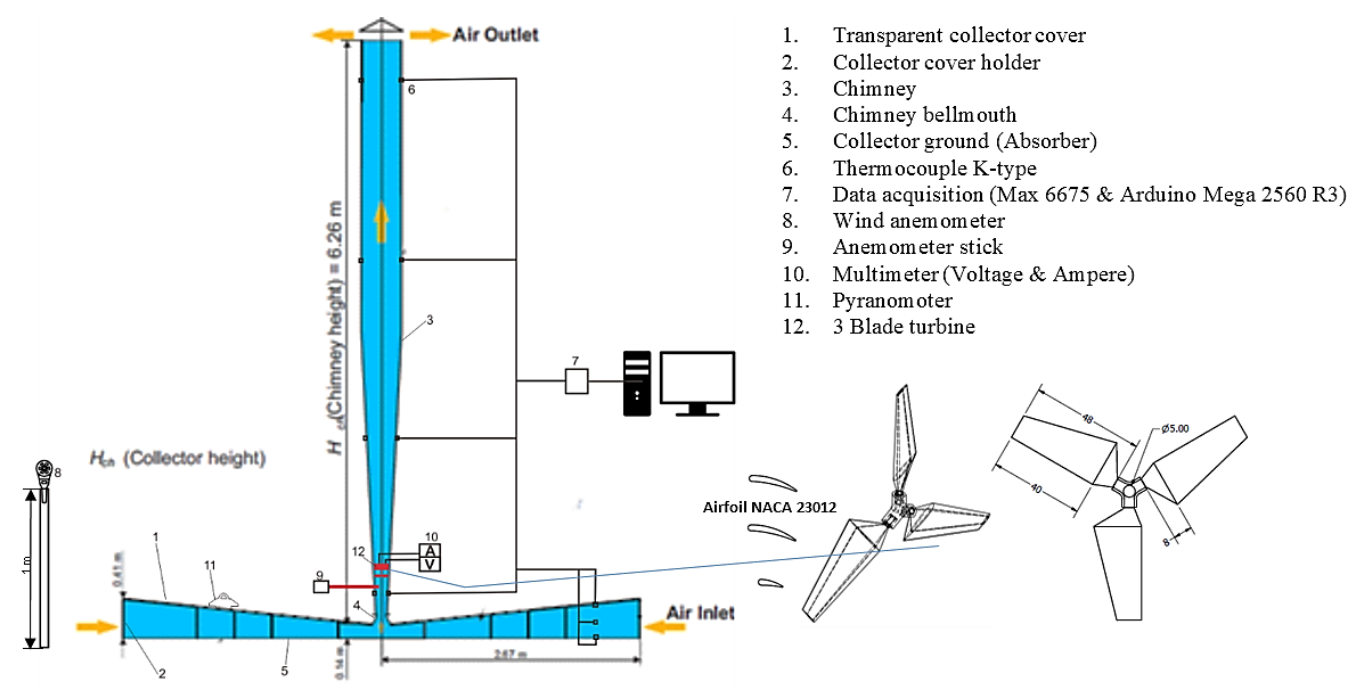

Figure 1. The schematic diagram of the experimental apparatus.

By assuming the chimney surface area $\left(A_{c h}\right)$, the value of air velocity in chimney neck $\left(v_{o, \text { coll }}\right)$ was obtained. The velocity of the chimney neck is the air velocity in the blade of turbine. 
The air velocity on chimney neck $\left(v_{o, c o l l}\right)$ was influenced by the gravitation, the height of chimney and the ratio of temperature difference to the ambient temperature. From assuming $v_{o, \text { coll }}$ dan $T_{\text {air }}$ the high of chimney will be obtained $H_{c h}$.

We can use equation bellow to find $H_{c h}$ :

$$
v_{o, \text { coll }}=\sqrt{2 \cdot g \cdot H_{c h} \cdot \frac{\left(T_{\text {air }}-T_{\text {ambient }}\right)}{T_{\text {ambient }}}}
$$

Design of air flow rate depend on the velocity of air in the chimney neck $\left(v_{o, \text { coll }}\right)$, chimney cross section area $\left(A_{c h}\right)$ and the air density in chimney $\left(\rho_{\text {air }}\right)$. From assuming $T_{\text {air }}$, we will get $\rho_{\text {air }}$. The additional variables $A_{c h}$ and $v_{o, \text { coll }}$ will be obtained air flow rate $(\dot{m})$ :

$$
\dot{m}=\rho_{\text {air }} \cdot A_{c h} \cdot v_{o, \text { coll }}
$$

By the assumption $T_{\text {air }}$, we would get $\mu, C_{p}, K_{\text {air }}, v$.

\subsection{Energy Balance of SCPP Collector}

The source of the energy was direct from the solar heat flux and the reflection of solar heat flux from ground to the cover. Those energy equal to the energy discharged by the collector's cover (convective heat transfer from the cover to the air flow inside the collector and heat losses from the cover into ambient atmospheric). The energy balance equation for the cover shown bellow:

$$
\left(I \cdot \alpha_{c} \cdot A_{c}+h_{r, g-c} \cdot A_{g} \cdot\left(T_{g}-T_{c}\right)\right)=\left(h_{c o n, c-a i r} \cdot A_{c} \cdot\left(T_{c}-T_{a i r}\right)+L_{u} \cdot A_{c} \cdot\left(T_{c}-T_{a m b}\right)\right)
$$

Transmissivity of solar heat flux equal to the energy discharged by the collector's ground, the convective heat transfer from the ground to the air flow in the collector, also the reflection of solar heat flux from the ground to the cover and the heat conduction on the ground. The energy balance equation for the collector's ground shown bellow:

$$
\left(I \cdot \tau_{c} \cdot \alpha_{g} \cdot A_{g}\right)=\left(\left[h_{c o n, g-a i r} \cdot A_{g} \cdot\left(T_{g}-T_{a i r}\right)\right]+\left[h_{r, g-c} \cdot A_{g} \cdot\left(T_{g}-T_{c}\right)\right]+\left[L_{d} \cdot A_{g} \cdot\left(T_{g}-T_{a m b}\right)\right]\right)
$$

The heat energy balance in the air inside of collector was the energy received by the air in the collector which equal to the energy released from the air inside of collector. There were convective heat transfer from cover to air and convective heat transfer from ground to air. The energy balance equation for the air inside collector shown bellow:

$$
\left(\dot{m} \cdot C_{p} \cdot\left(T_{\text {air }, o}-T_{\text {air }, i}\right)\right)=\left(\left[h_{c o n, c-a i r} \cdot A_{c} \cdot\left(T_{c}-T_{\text {air }}\right)\right]+\left[h_{\text {con, }, \text {-air }} \cdot A_{g} \cdot\left(T_{g}-T_{\text {air }}\right)\right]\right)
$$

Generally there were three equations of collector energy balance : the cover energy balance, the ground energy balance and the air inside collector energy balance. Those equations can be solved by iteration methode with Microsoft Excel Solver with energy balance validation $<5 \%$. We can got $T_{a i r}, T_{g}, T_{c}$ with assumption $A_{g}=A_{c}$. All variables are entered into the energy balance equation to got the area of $A_{c h}, A_{g}$ and $A_{c}$ and high chimney $H_{c h}$.

$$
A=\frac{\left(\dot{m} \cdot C_{p} \cdot\left(T_{\text {air }, o}-T_{\text {air }, i}\right)\right)}{\left(\left[h_{\text {con }, c-\text { air }} \cdot\left(T_{c}-T_{\text {air }}\right)\right]+\left[h_{\text {con }, g-\text { air }} \cdot\left(T_{g}-T_{\text {air }}\right)\right]\right)}
$$


The results of iteration using Microsoft Excel Solver with validation of cross-sectional area and energy balance $<5 \%$, then got the area of $A_{c h}, A_{g}$ and $A_{c}$ and high chimney $H_{c h}$. The initial design variables that has known also has assumed. The calculation did multiple times until get the collector cross-sectional area both on the collector's cover $\left(A_{c}\right)$ and on the collector's ground $\left(A_{g}\right)$ which has convergent result. Cross sectional area was circles so the length of the collector's diameter could be calculated as follow:

$$
D_{\text {coll }}=\sqrt{\frac{A_{\text {coll }}}{\frac{\pi}{4}}}
$$

\section{RESULT AND DISCUSSION}

The variables was needed to determine the dimensions of SCPP design such as the solar radiation $\left(1118 \mathrm{~W} / \mathrm{m}^{2}\right)$, the absorptivity of acrylic cover collector $(0.04)$, the ambient temperature $T_{a m b}$ based on BMKG data $\left(28.8^{\circ} \mathrm{C}\right.$ or $\left.301.8 \mathrm{~K}\right)$, the transmissivity of acrylic cover collector (0.92), the absorptivity of ground gravel collector with non-metallic dark color (0.16), conductivity of ground gravel $\left(0.7 \frac{\mathrm{W}}{\mathrm{m}^{2} \mathrm{~K}}\right)$, the constan of Stefan Boltzman $\left(5.6697 * 10^{-8} \frac{\mathrm{W}}{\mathrm{m}^{2} \mathrm{~K}^{4}}\right)$, the ground gravel emissivity with dark black (0.94), the acrylic cover collector emissivity (0.94) and the ambient wind speed $(5.27 \mathrm{~m} / \mathrm{s})$.

The data variables were obtained from the literature study and will be used to design the SCPP dimensions such as the cross-sectional area of the ground collector and cover collector with equal value, $A_{g}=A_{c}$ of $24.09 \mathrm{~m}^{2}$. The cross-sectional area of the chimney neck is $A_{c h}=$ $0.011304 \mathrm{~m}^{2}$, the average temperature of the working fluid is $321.52 \mathrm{~K}$, the average temperature of the ground collector is $345.81 \mathrm{~K}$, the average temperature of collector's acrylic cover is 308.20 $\mathrm{K}$, the inclination angle of collector's acrylic cover is $3^{\circ}$ and the space between collector's ground and collector's acrylic cover is $0.275 \mathrm{~m}$. The height of chimney is $6.26 \mathrm{~m}$, it obtained from the calculation of velocity design which is affected by the gravitation.

Table 2 is the result from theoritical calculation, that value obtained by data variables from design of SCPP. It shows the data are used in the theoretical calculation design to know the power generated from the 3 blades turbine generator. The solar heat flux used is $1118 \mathrm{~W} / \mathrm{m}^{2}$ which produces the output power 0.07 Watts. Those power value used as a reference in this study to compare with experimental output power in the same of the solar heat flux variable.

Table 1. Assumption and Environment Conditions

\section{Variable}

Solar radiation $(I)$

Accrylic collector cover absorptivity $\left(\alpha_{c}\right)$

Ambient temperature $\left(\boldsymbol{T}_{a m b}\right)$

Accrylic collector cover transmissivity $\left(\tau_{c}\right)$

Gravel ground collector absorptivity $\left(\alpha_{g}\right)$
$1118 \mathrm{~W} / \mathrm{m}^{2}$

$301.8 \mathrm{~K}$

0.92

0.16 
H.M.I. Paska et al. / Journal of Mechanical Design and Testing 2(1), (2020), 21-35

Gravel ground collector conductivity $\left(L_{d}\right)$

Stefan-Boltzman constant $(\sigma)$

Gravel ground collector emissivity $\left(\varepsilon_{g}\right)$

Accrylic collector cover emissivity $\left(\varepsilon_{c}\right)$

Ambient wind speed $\left(u_{w}\right)$

Average temperature of working fluid $\left(\boldsymbol{T}_{\text {air }}\right)$

Average temperature of ground collector $\left(T_{g}\right)$

Average temperature of accrylic collector cover $\left(\boldsymbol{T}_{c}\right)$

Slope angle of accrylic collector $\operatorname{cover}(\theta)$

Average distance between ground collector and accrylic collector cover $\left(L_{g-c}\right)$

$$
\begin{gathered}
0.7 \frac{W}{m^{2} K} \\
5.6697 * 10^{-8} \frac{W}{m^{2} K^{4}}
\end{gathered}
$$

0.94

$5.27 \mathrm{~m} / \mathrm{s}$

$321.52 \mathrm{~K}$

$345.81 \mathrm{~K}$

$308.20 \mathrm{~K}$

$3^{\circ}$

$0.275 \mathrm{~m}$

\subsection{The Effect of Solar Intensity to The Air Temperaure}

Figure 2 shows a correlation between solar heat flux $(I)$ and the temperature (ambient temperature $\left(T_{a m b}\right)$, air temperature in the neck chimney $\left(T_{\text {air }, o}\right)$, temperature on the cover $\left(T_{c}\right)$ and temperature on ground $\left(T_{g}\right)$. That figure shows that the increasing of solar intensity will causes increasing all of the temperature, those are an ambient temperature $\left(T_{a m b}\right)$,air temperature on the chimney neck $\left(T_{a i r, o}\right)$, temperature on the cover $\left(T_{c}\right)$ and temperature on ground $\left(T_{g}\right)$. The increasing of temperature occurred because the more the solar heat flux $(I)$ received, the more heat was received. As we know that the heat proportional to the temperature.

\subsection{The Effect of Solar Intensity to The Air Velocity}

Figure 3 shows a correlation between solar heat flux $(I)$ and air velocity both ambient air velocity $\left(u_{w}\right)$ and air velocity on the chimney neck $\left(v_{o, c o l l}\right)$. That figure shows the increasing of solar heat flux $(I)$ will cause the ambient air temperature $\left(T_{a m b}\right)$ and chimney neck temperature $\left(T_{\text {air }, o}\right)$ increase. The increasing of temperatures caused by increasing of the air volume and the density of the air decreased. The change of air density on the collector and chimney neck will be effect a high pressure. Then the high presure will be effect a buoyancy force on the chimney neck, the buoyancy force will moved upward to low pressure area. The air mass flow rate caused the increasing of air velocity ( $\left(\right.$ ambient air velocity $\left(u_{w}\right)$ and air velocity on the chimney neck $\left.\left(v_{o, \text { coll }}\right)\right)$. The air mass flow rate caused the increasing of air velocity $\left(\left(\operatorname{ambient}\right.\right.$ air velocity $\left(u_{w}\right)$ and air velocity on the chimney neck $\left.\left(v_{o, c o l l}\right)\right)$. 
H.M.I. Paska et al. / Journal of Mechanical Design and Testing 2(1), (2020), 21-35

Table 2. Theoritical Calculation

\begin{tabular}{|c|c|c|c|c|c|c|c|}
\hline $\begin{array}{c}\text { Solar } \\
\text { radiatio } \\
\mathbf{n} \\
(\mathrm{W} / \\
\left.\mathrm{m}^{2}\right)\end{array}$ & $\begin{array}{c}\text { Ambient } \\
\text { temperatu } \\
\text { re (K) }\end{array}$ & $\begin{array}{c}\text { Ambie } \\
\text { nt } \\
\text { wind } \\
\text { speed } \\
(\mathrm{m} / \mathrm{s})\end{array}$ & $\begin{array}{c}\text { Air } \\
\text { temperatu } \\
\text { re on the } \\
\text { chimney } \\
\text { neck }\end{array}$ & $\begin{array}{l}\text { Temperatu } \\
\text { re of cover } \\
\text { (K) }\end{array}$ & $\begin{array}{l}\text { Temperatu } \\
\text { re of } \\
\text { ground }(K)\end{array}$ & $\begin{array}{c}\text { Air } \\
\text { velocit } \\
\text { y on } \\
\text { the } \\
\text { chimn } \\
\text { ey } \\
\text { neck } \\
(\mathrm{m} / \mathrm{s})\end{array}$ & $\begin{array}{c}\text { Power } \\
\text { generat } \\
\text { ed from } \\
\text { a } 3 \\
\text { blade } \\
\text { turbine } \\
\text { generat } \\
\text { or (W) }\end{array}$ \\
\hline 1118 & 301.8 & 5.27 & 341.24 & 308.20 & 345.81 & 2.83 & 0.07 \\
\hline
\end{tabular}

\subsection{The Effect of Solar Intensity to The Electrical Power}

Figure 4 shows a correlation between solar heat flux $(I)$ and electrical power generated from a 3 blade turbine generator $\left(P_{\text {ele }}\right)$. This figure shows the incrasing of the solar heat flux $(I)$ will cause velocity of air increased in the chimney neck $\left(v_{o, \text { coll }}\right)$. The increasing of air velocity at the chimney neck $\left(v_{o, \text { coll }}\right)$ causes the air moved to the turbine faster and the kinetic power of the wind increased. The turbine's rotation causes the rpm rotation increase and decreased the torque so the turbine energy will be higher. The energy of turbine after adjusting to the efficiency of generator can be converted to electrical energy $\left(P_{\text {ele }}\right)$.

\subsection{The Correlation of Velocity and Electrical Power}

Figure 5 shows a correlation between air velocity (both ambient air velocity $\left(u_{w}\right)$ and air velocity on the chimney neck $\left.\left(v_{o, \text { coll }}\right)\right)$ and electrical power generated from a 3 blade turbine generator $\left(P_{\text {ele }}\right)$. As mentioned before that the increasing of air velocity at the chimney's neck $\left.\left(v_{o, \text { coll }}\right)\right)$ causes the air move to the turbine faster and it makes the wind's kinetic power is higher. The turbine's rotation causes the rpm rotation increase and decreased the torque so the turbine energy will be higher. The energy of turbine after adjusting to the efficiency of generator can be converted to the electrical energy $\left(P_{\text {ele }}\right)$.

Figure 6 shows a comparation between the solar heat flux $(I)$ with the power generated from the experiment. The figure shows the value of the solar heat flux $(I)$ starting from 8:25 a.m. has increased until at 12:25 a.m. and then the solar heat flux $(I)$ has decreased. Figure 6 also shows the value of the power generated at 8:25 a.m until 5:25 p.m. The result data are fluctuating. The highest power generated at 11:25 a.m with a power precentage of 0.10 Watts and the solar heat flux is $1118 \mathrm{~W} / \mathrm{m}^{2}$. In the experiment, the high solar heat flux does not directly have a constant effect on the amount of power, so the power produced fluctuates but overall still has a positive correlation. The high electrical power is influenced by the amount of kinetic power. The kinetic power is influenced by the density of air, area and air velocity at the chimney's neck. The constant temperature difference between ambient temperature and ground temperature as well as between ambient temperature and the temperature at the chimney's neck results in uniform air velocity to the flow of air entering through the inlet collector to the collector and from the collector to the chimney. Air velocity and density at the chimney neck affect the amount of wattage produced. However, as the temperature and temperature changes in the chimney neck in the rainy season also influence the air velocity and density so that the wattage generated even though the solar heat flux is high. In the first step, the effect of the heat flux cannot be absorbed evenly throughout the ground, this causes a non-uniform temperature difference, unconcentrated airflow and finally reducing the kinetic energy possessed by the air. 
From Figure 6 we can see that the output power resulting from the eksperimen have higher value than the output power from target. The experiment resulting electrical power 0.1 Watt while the electrical power which has determined before is 0.07 Watt. From that result we can conclude that with the same intensity used, the electrical power resulting from experiment is higher than the theoritical design calculation.

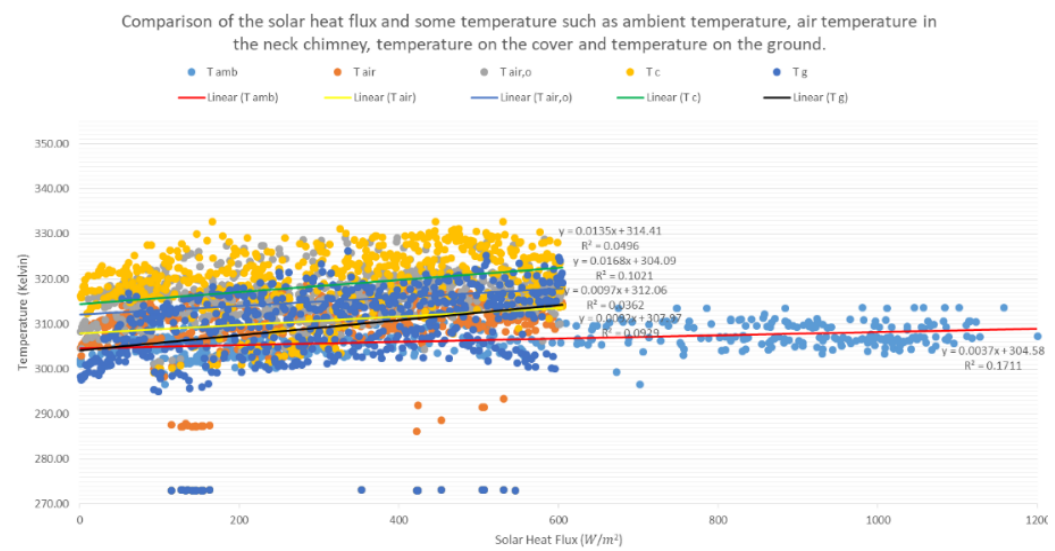

Figure 2. Comparison of the solar heat flux and some temperature such as ambient temperature, air temperature in the chimney neck, temperature on the cover and temperature on the ground.

Table 3. Experiment results

\begin{tabular}{|c|c|c|c|c|c|c|c|}
\hline $\begin{array}{c}\text { Solar } \\
\text { radiatio } \\
\mathbf{n} \\
(\mathbf{W} / \\
\left.\mathbf{m}^{2}\right)\end{array}$ & $\begin{array}{c}\text { Ambient } \\
\text { temperatur } \\
\text { e (K) }\end{array}$ & $\begin{array}{c}\text { Ambien } \\
t \text { wind } \\
\text { speed } \\
(\mathrm{m} / \mathrm{s})\end{array}$ & $\begin{array}{c}\text { Air } \\
\text { temperatur } \\
\text { e on the } \\
\text { chimney } \\
\text { neck (K) }\end{array}$ & $\begin{array}{l}\text { Temperatur } \\
\text { e of cover } \\
\text { (K) }\end{array}$ & $\begin{array}{l}\text { Temperatur } \\
\text { e of ground } \\
\text { (K) }\end{array}$ & $\begin{array}{c}\text { Air } \\
\text { velocity } \\
\text { on the } \\
\text { chimne } \\
\text { y neck } \\
(\mathrm{m} / \mathrm{s})\end{array}$ & $\begin{array}{c}\text { Power } \\
\text { generate } \\
\text { d from a } \\
3 \text { blade } \\
\text { turbine } \\
\text { generato } \\
\mathrm{r}(\mathrm{W})\end{array}$ \\
\hline 1118 & 304.6 & 5.3 & 331.98 & 310.77 & 325.74 & 2.47 & 0.10 \\
\hline
\end{tabular}

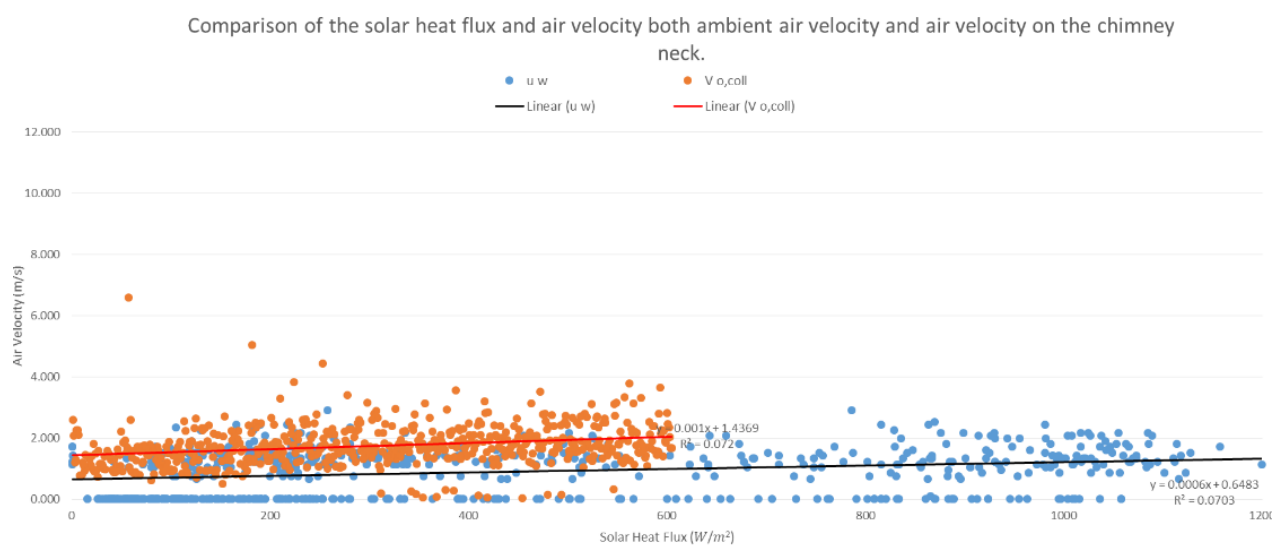

Figure 3. Comparison of the solar heat flux and air velocity both ambient air velocity and air velocity on the chimney neck 
H.M.I. Paska et al. / Journal of Mechanical Design and Testing 2(1), (2020), 21-35

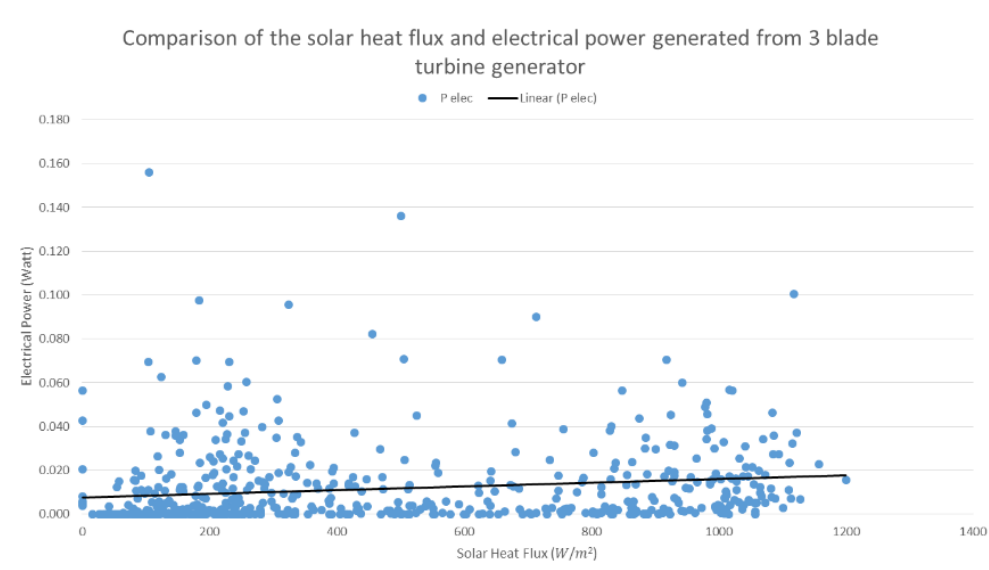

Figure 4. Comparison of the solar heat flux and electrical power generated from 3 blade turbine generator

Table 4. Comparison of theoretical calculation designs with experiment results

\begin{tabular}{|c|c|c|c|c|c|c|c|c|}
\hline $\begin{array}{l}\text { Descripti } \\
\text { on }\end{array}$ & $\begin{array}{c}\text { Solar } \\
\text { radiati } \\
\text { on } \\
(\mathrm{W} / \\
\left.\mathbf{m}^{2}\right)\end{array}$ & $\begin{array}{c}\text { Ambient } \\
\text { temperat } \\
\text { ure (K) }\end{array}$ & $\begin{array}{c}\text { Ambie } \\
\text { nt } \\
\text { wind } \\
\text { speed } \\
(\mathrm{m} / \mathrm{s})\end{array}$ & $\begin{array}{c}\text { Air } \\
\text { temperat } \\
\text { ure on } \\
\text { the } \\
\text { chimney } \\
\text { neck (K) }\end{array}$ & $\begin{array}{c}\text { Temperat } \\
\text { ure of } \\
\text { cover (K) }\end{array}$ & $\begin{array}{l}\text { Temperat } \\
\text { ure of } \\
\text { ground } \\
\text { (K) }\end{array}$ & $\begin{array}{c}\text { Air } \\
\text { velocit } \\
\text { y on } \\
\text { the } \\
\text { chimn } \\
\text { ey } \\
\text { neck } \\
(\mathrm{m} / \mathrm{s})\end{array}$ & $\begin{array}{c}\text { Power } \\
\text { generat } \\
\text { ed from } \\
\text { a } 3 \\
\text { blade } \\
\text { turbine } \\
\text { generat } \\
\text { or (W) }\end{array}$ \\
\hline $\begin{array}{l}\text { Theoritic } \\
\text { al } \\
\text { Calculati } \\
\text { on }\end{array}$ & 1118 & 301.8 & 5.27 & 341.24 & 308.20 & 345.81 & 2.83 & 0.07 \\
\hline $\begin{array}{l}\text { Experim } \\
\text { ent } \\
\text { results }\end{array}$ & 1118 & 304.6 & 5.3 & 331.98 & 310.77 & 325.74 & 2.47 & 0.10 \\
\hline
\end{tabular}

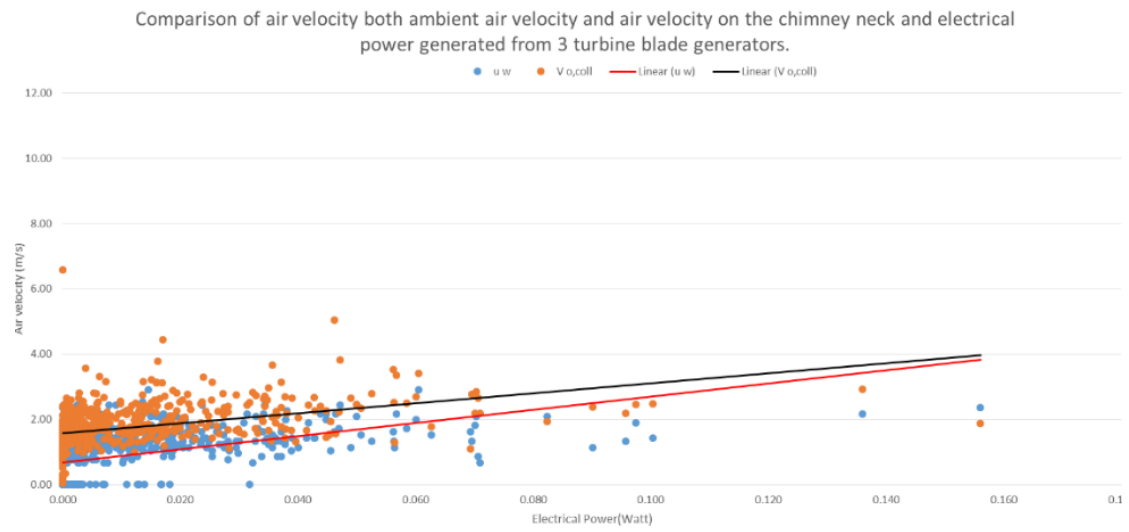

Figure 5. Comparison of both air velocity and air velocity on the chimney neck and electrical power generated from 3 turbine blade generation 
Figure 7 shows the value of the power generated from the experimental results very high at 11:25 a.m, this happens at 11:25 a.m using the solar heat flux $(I)$ value of $1118 \mathrm{~W} / \mathrm{m}^{2}$ has the same solar heat flux $(I)$ value used in the design. It can be concluded the power generated in the experimental results is greater than the target of the electrical power obtained theoretically because in the design of theoretical calculations, it is assumed that the straight chimney is not divergent and the divergent collector but in the experiment the chimney is divergent, the divergent collector and the collector ground are used asphalt layers at the top and then concrete also gravel. Those material is good to absorb and store heat. The other data below of targeted electrical power because the values of solar heat flux $(I)$ are used different between experiment and theoretical.

From Figure 7 we can see that the desired target has not been reached. Things that cause the target has not been reached the target has not been reached because of many losses in this solar chimney system. One of the losses that occur is due to the flow of air that is not uniform and not concentrated toward the chimney. This causes the airflow to collide with each other inside the collector which causes a reduction in the air's kinetic energy. Therefore, a solution offered to achieve the target are:

1. Creating an air-channel that connects the ambient airflow from the inlet collector to the collector and from the collector to the chimney. This making the airflow produced air velocity that rotates the turbine with 3 blades to produce optimal power.

2. Maintaining a constant temperature difference between ambient temperature and ground temperature and between ambient temperature and the temperature at the chimney neck produces an air velocity equivalent to the flow of air entering through the inlet collector to the collector and from the collector to the chimney.

Both air velocity and density can make the electric power produced constant and reach the maximum target. This can only be done in a laboratory, but it is difficult to do in an open environment that requires natural phenomena.

In Table 3 we can also shows the value of air temperature at the chimney neck, temperature at ground and velocity of air at the chimney neck. The theoretical calculation design is higher than the experimental results, it happened because the lower chimney neck air temperature, ground temperature and velocity of air at the chimney neck then the value of the power generated from the 3 blade turbine generator at the solar chimney power plant is getting higher.

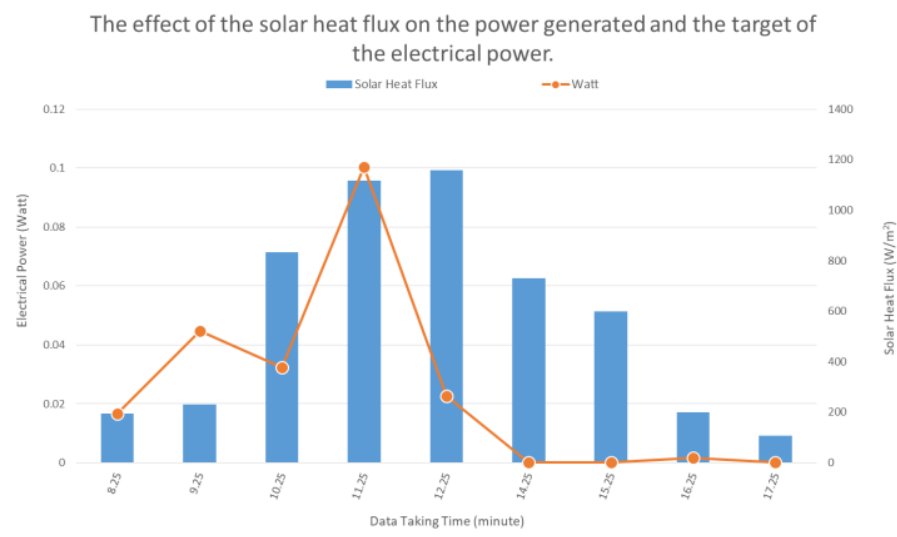

Figure 6. The effect of the solar heat flux on the power generated 


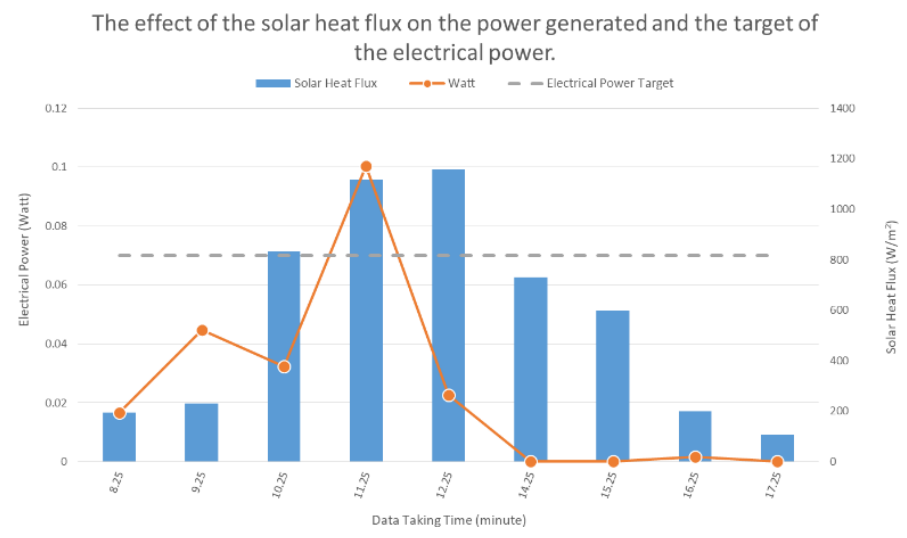

Figure 7. The effect of the solar heat flux on the power generated and the target of the electrical power

In Table 4 shows a comparison between the design of theoretical calculations with experimental results. By using the same value of sunlight intensity will be obtained ambient temperature, ambient wind velocity, temperature on the cover, velocity of air at the chimney neck and the power generated. From the table shows the result from experimental is higher than theoretical calculation design. This shows that the increasing of ambient temperature, ambient wind velocity, temperature on the cover and velocity of air at the chimney neck, the power generated from the 3 blade turbine generator at the SCPP is also increased.

From the results of the output power, the increase in output power generated due to the optimization of the shape of the convergent collector, divergent chimney shaped and 3 blades turbine by:

$$
\begin{aligned}
\Delta P_{\text {out }} & =\left(\frac{P_{\text {ex }}-P_{\text {th }}}{P_{\text {th }}}\right) \times 100 \% \\
& =\left(\frac{0.10-0.07}{0.07}\right) \times 100 \% \\
& =42.8 \%
\end{aligned}
$$

where $\Delta P_{\text {out }}$ is an increase in SCPP output power. $P_{e x}$ is the output power generated in the experiment. $P_{t h}$ is the output power generated in the theoritical calculation design. 


\section{CONCLUSION}

The results obtained from this study are as follows:

1. The results of energy balance calculation on the cover, on the working fluid (air) and on the ground produce the basic dimensions of the SCPP design using iteration solving methode. The dimension result from that methode were $A_{g}=A_{c}=24.09 \mathrm{~m}^{2}, A_{c h}=0.011304 \mathrm{~m}^{2}$ dan $H_{c h}=6.26 \mathrm{~m}$. Those basic design used to build SCPP system with output power target $0.07 \mathrm{~W}$. With that output power target, the other dimension like the diameter of colector's cover is $5.538 \mathrm{~m}$, the diameter of chimney is $0.200 \mathrm{~m}$, the diameter of the chimney neck is $0.120 \mathrm{~m}$, and the average distance between collector's cover and the collector's background is $0.275 \mathrm{~m}$.

2. The optimized design that created to improve SCPP system performance by making a chimney with divergent shape, a collector with convergent shape, a turbine with 3 blade, and the collector's ground that coated at the top side with asphalt using concrete and gravel for the materials.

3. The increasing of the solar heat flux $(I)$ proportional with increasing of the ambient temperature $\left(T_{a m b}\right)$, the collector cover temperature $\left(T_{c}\right)$, the collector ground temperature $\left(T_{g}\right)$ impact on increasing the air inside collector temperature $\left(T_{\text {air }}\right)$ flowing through the collector and flow up to the chimney increasing the chimney's neck temperature $\left(T_{\text {air }, o}\right)$.

4. The increasing of the solar heat flux $(I)$ proportional with increasing of the ambient velocity $\left(u_{w}\right)$ and the air velocity in the chimney neck $\left(v_{o, \text { coll }}\right)$.

5. The increasing of ground temperature $\left(T_{g}\right)$ and temperature at the chimney neck $\left(T_{\text {air,o }}\right)$ impact on increasing of air velocity at the chimney neck, thus also impact to increasingly the power generated from the 3 blade turbine generator at the solar chimney power plant.

6. The material for layer on collector ground is effect to generated a power. The asphalt material used in the ground collector is better as an absorber material so that it can take a long time to store heat to heat the flow of ambient air entering the collector. The better the absorption of solar radiation by asphalt material, the greater the heat transfer that can be delivered by ground to air in the collector. In addition, a uniform application of asphalt in the collector will cause a constant temperature in the soil causing a difference between the ambient temperature and the ground temperature and between the ambient temperature and the temperature at the neck of the chimney to produce an even velocity of air to the flow of air entering through the inlet collector to the collector and from the collector to the chimney. It also can maintain the temperature in the chimney neck constant so that it can produce a large density in the chimney neck. Both the constant air velocity and density can affect the electric power generated.

7. In the experimental results the highest power generated at 11:25 a.m., which is equal to 0.10 Watts with the solar intensity was $1118 \mathrm{~W} / \mathrm{m}^{2}$. 


\section{REFERENCES}

A. Koonsrisuk and T. Chitsomboon, 2013, "Mathematical modeling of solar chimney power plants," Energy, vol. 51, pp. 314-322.

A. Ridwan, H. Hafizh, and M. R. Fauzi, 2018, "Design and experimental test for solar chimney power plant: Case study in Riau Province, Indonesia,” IOP Conf. Ser. Mater. Sci. Eng., vol. 403, no. 1 , pp. $0-8$.

L. Zuo et al., 2019, "Performance analysis of a wind supercharging solar chimney power plant combined with thermal plant for power and freshwater generation," Energy Convers. Manag., no. August, p. 11228.

M. A. Aurybi, S. I. Gilani, H. H. Al-Kayiem, and A. A. Ismaeel, 2018, "Mathematical evaluation of solar chimney power plant collector, integrated with external heat source for noninterrupted power generation," Sustain. Energy Technol. Assessments, vol. 30, no. December 2016, pp. 59-67.

M. A. dos S. Bernardes and T. W. von Backström, 2010, "Evaluation of operational control strategies applicable to solar chimney power plants," Sol. Energy, vol. 84, no. 2, pp. $277-$ 288.

M. Ghalamchi, A. Kasaeian, M. Ghalamchi, and A. H. Mirzahosseini, 2016, “An experimental study on the thermal performance of a solar chimney with different dimensional parameters," Renew. Energy, vol. 91, pp. 477-483.

S. Dehghani and A. H. Mohammadi, 2014, "Optimum dimension of geometric parameters of solar chimney power plants - A multi-objective optimization approach," Sol. Energy, vol. 105, pp. 603-612.

S. Hu, D. Y. C. Leung, and M. Z. Q. Chen, 2017,"Effect of Divergent Chimneys on the Performance of a Solar Chimney Power Plant,” Energy Procedia, vol. 105, pp. 7-13.

T. U. of the S. P. Patel, Sandeep Kumar, 2013, (School of Engineering and Physics, Faculty of Science, Technology, and Environment, "Computational and Experimental Studies on a Solar Chimney Power Plant," The University of the South Pacific.

X. Zhou, J. Yang, B. Xiao, and G. Hou, 2007, "Experimental study of temperature field in a solar chimney power setup,” Appl. Therm. Eng., vol. 27, no. 11-12, pp. 2044-2050. 